Jurnal Ilmiah ESAI Volume 13, No. 2, Juli 2019

p-ISSN 1978-6034 e-ISSN 2580-4944

Market Reactions on Audited Interim Financial Statements Publication: an Empirical Study on Public Companies in Indonesia Stock Exchange

\title{
Reaksi Pasar atas Publikasi Laporan Keuangan Interim Diaudit Studi Empiris pada Perusahaan-Perusahaan yang Mempublik di Bursa Efek Indonesia
}

Irawan $^{1}$ ), Arif Makhsun ${ }^{2}$

${ }^{1,2)}$ Program Studi Akuntansi Jurusan Ekonomi dan Bisnis Polinela

\begin{abstract}
This study was conducted on interim financial statements of companies included in the calculation of the KOMPAS 100 index on the Indonesia Stock Exchange (IDX) with the consideration that the companies' shares included in the KOMPAS 100 index on average per year control more than $75 \%$ in volume trade and market capitalization on the Indonesia Stock Exchange (IDX) so that it is considered the most widely traded stock. Hence, it is expected that many interested parties (especially active investors) of the interim financial report and use accounting information from the company in its investment decisions. The study was conducted on quarterly financial statements, mid-year financial reports and quarterly financial statements.

The results of this study indicate that the market responds widely to the announcement of the Interim Financial Report I and Interim Financial Report II published by the issuer. On the other hand the market does not respond broadly to the announcement of the Interim Financial Report III published by the issuer.

The involvement of auditors in interim financial reports in the form of reviews and complete audits does not have an impact on improving the quality of information on interim financial statements received by investors. This is demonstrated by the absence of differences in market reactions to the publication of interim financial statements.
\end{abstract}

Keywords: Interim Financial Reports, Market Reactions

\section{Pendahuluan}

Reaksi pasar merupakan indikator terhadap penggunaan dan kebermanfaatan laporan keuangan oleh investor. Suatu publikasi laporan keuangan dikatakan mengandung informasi kalau publikasi laporan keuangan tersebut menyebabkan perubahan keyakinan penerima (investor di pasar modal) dan memicu tindakan tertentu yang tercermin dalam perubahan harga atau volume saham di pasar modal. Jika tindakan tersebut dapat diyakini sebagai akibat informasi dalam publikasi laporan keuangan tersebut maka dapat dikatakan informasi tersebut bermanfaat. Dalam hal ini, perubahan harga atau volume saham yang diamati memberi bukti adanya kebermanfaatan informasi. Dengan kata lain, ketika suatu pengumuman (keuangan atau non keuangan) masuk ke bursa saham kemudian pelaku bursa saham merespon pengumuman tersebut maka pengumuman tersebut dikatakan mengandung informasi. 
Penelitian mengenai reaksi pasar pada laporan keuangan interim telah banyak dilakukan di luar negeri maupun di Indonesia. Indrastanti (1998) menguji apakah laporan keuangan interim yang dipublikasikan ke publik mengandung informasi sehingga mempengaruhi harga saham (pasar bereaksi). Dengan menggunakan sampel sebanyak 235 laporan keuangan interim di Bursa Efek London, peneliti melaporkan bahwa laporan keuangan interim mengandung informasi yang mempengaruhi aktivitas harga saham disekitar tanggal publikasi. Landsman, et al (2012) menguji evolusi kandungan informasi dari pengumuman laba kuartalan selama 3 dekade di pasar Amerika untuk melihat kecenderungan reaksi pasar atas publikasi laporan keuangan interim selama 3 dekade terakhir. Dengan menggunakan varian return abnormal dan volume perdagangan abnormal disekitar pengumuman laba, peneliti melaporkan bahwa kandungan informasi dari pengumuman laba kuartalan di Amerika Serikat meningkat secara signifikan selama 30 tahun terakhir.

Hasil-hasil penelitian yang tidak konsisten dengan riset-riset sebelumnya telah dilaporkan di Indonesia. Jatiningrum (2009) menemukan bukti empiris yang menyatakan bahwa publikasi laporan keuangan interim tidak berpengaruh secara signifikan terhadap return saham abnormal untuk seluruh interim I, II, III. Hasil penelitian ini konsisten dengan penelitian yang dilakukan oleh Hakim dalam Jatiningrum (2009) yang menyimpulkan bahwa publikasi laporan keuangan interim tidak mempunyai pengaruh yang signifikan terhadap return saham abormal karena informasi akuntansi yang berupa laporan interim terlalu lambat diterima oleh investor sehingga menjadikan laporan keuangan interim tidak relevan. Hasil yang sama juga ditunjukkan oleh Suyatno (2003). Hasil penelitiannya menunjukkan bahwa tidak ada pengaruh yang berarti antara pengumuman laporan keuangan interim dengan harga saham.

Selain bermanfaat, keterlibatan auditor dalam laporan keuangan interim juga menimbul-kan beberapa konsekuensi diantara peningkatan biaya audit yang signifikan yang sebenarnya tidak harus terjadi dan penundaan penyampaian laporan keuangan interim yang akan mengurangi relevansi laporan tersebut Mangena dan Tauringana (2012). Bedard dan Courteau (2004), menggunakan sampel sebanyak 1690 perusahaan di Kanada, menemukan bukti bahwa biaya audit untuk perusahaan yang melakukan reviu audit terhadap laporan keuangan interimya $15 \%$ lebih tinggi dibandingkan dengan perusahaan yang tidak melakukan reviu terhadap laporan keuangan interimnya.

\section{Kajian Pustaka}

\section{Reaksi Pasar dan Kandungan Informasi}

Suatu pesan atau kejadian dikatakan mengandung informasi kalau pesan tersebut menyebabkan perubahan keyakinan penerima (investor di pasar modal) dan memicu 
tindakan tertentu yang tercermin dalam perubahan harga atau volume saham di pasar modal. Jika tindakan tersebut dapat diyakini sebagai akibat informasi dalam pesan tersebut maka dapat dikatakan informasi tersebut bermanfaat. Dalam hal ini, perubahan harga atau volume saham yang diamati memberi bukti adanya kebermanfaatan informasi. Jika pengumuman mengandung informasi maka diharapkan pasar akan bereaksi pada waktu pengumuman tersebut diterima oleh pasar. Reaksi pasar ditunjukkan dengan adanya perubahan harga dari sekuritas yang bersangkutan. Reaksi ini dapat diukur dengan menggunakan abnormal return sebagai nilai perubahan harga yang melebihi harapan pasar.

\section{Laporan keuangan interim}

Pernyataan Standar Akuntansi Keuangan Nomor 3 mendefinisikan laporan keuangan interim sebagai laporan keuangan yang berisi baik laporan keuangan lengkap (PSAK NO 1 tentang Penyajian Laporan Keuangan) atau laporan keuangan ringkas untuk suatu periode interim. Periode interim adalah suatu periode laporan keuangan yang lebih pendek dari satu tahun buku penuh. Sedangakan Bursa Efek Indonesia mendefinisikan laporan keuangan interim adalah laporan keuangan triwulan I, laporan keuangan tengah tahunan dan laporan keuangan triwulan III.

Laporan keuangan interim dapat disajikan dalam bentuk laporan keuangan lengkap atau laporan keuangan ringkas.
PSAK Nomor 1 tentang penyajian laporan keuangan menetapkan laporan keuangan lengkap meliputi: 1) laporan posisi keuangan pada akhir periode; b) laporan laba rugi komprehensif selama periode; 3) laporan perubahan ekuitas selama periode; 4) laporan arus kas selama periode; 5) catatan atas laporan keuangan, berisi ringkasan kebijakan akuntansi penting dan informasi penjelasan lain; dan 6) laporan posisi keuangan pada awal periode komparatif yang disajikan ketika entitas menerapkan suatu kebijakan. Laporan minimal mencakup komponen: 1) laporan posisi keuangan ringkas; 2) laporan laba rugi komprehensif ringkas, yang disajikan: (a) dalam satu laporan laba rugi komprehensif ringkas; atau (b) dalam satu laporan laba rugi ringkas terpisah dan satu laporan laba rugi komprehensif ringkas.

\section{Regulasi Publikasi Laporan Keuangan Interim}

Publikasi laporan keuangan interim kepada publik merupakan kewajiban bagi setiap emiten. Hal ini dapat diketahui melalui peraturan Bursa Efek Indonesia Nomor I-E tentang kewajiban penyampaian informasi point III.1.1 yang berbunyi sebagai berikut: "Perusahaan Tercatat wajib menyampaikan Laporan Keuangan secara berkala ke Bursa yang meliputi: Laporan Keuangan tahunan dan laporan Keuangan Interim.... Laporan Keuangan Interim adalah Laporan Keuangan triwulan I, Laporan Keuangan tengah tahunan dan Laporan Keuangan triwulan III" 


\section{Pengujian Hipotesis}

Hipotesis pertama dan kedua dalam penelitian ini adalah Terdapat reaksi pasar atas publikasi Laporan Keuangan Interim I, II, dan III dan Terdapat reaksi pasar atas publikasi laporan keuangan interim diaudit untuk Laporan Keuangan Interim I, II, dan III. Kriteria suatu publikasi laporan atau peristiwa dikatakan direaksi pasar jika varian retur abnormalnya lebih dari satu (AVAR > 1) dan atau volume perdagangan abnormalnya positif ( AVOL > 0). Oleh karena itu digunakan uji beda satu sisi kanan (one tail t-test) terhadap AVAR dan AVOL selama periode jendela ( $\mathrm{t}-5$ sampai dengan $t+5)$ dengan perumusan hipotesis statistiknya sebagai berikut :

$H_{O}: \mu_{A V A R, x, y} \leq 1$

$H_{a}: \mu_{A V A R, x, y}>1$

$H_{O}: \mu_{A V O L, x, y} \leq 0$

$H_{a}: \mu_{A V O L, x, y}>0$

$x$ adalah bentuk keterlibatan auditor dalam laporan keuangan interim (audited, review, unaudited). $y$ adalah laporan keuangan triwulan I, laporan keuangan triwulan II, laporan keuangan triwulan III.

\section{Metode Penelitian}

Penelitian ini dilakukan pada laporan keuangan interim dari perusahaanperusahaan yang masuk dalam perhitungan indeks KOMPAS 100 di Bursa Efek Indonesia (BEI) dengan pertimbangan bahwa saham perusahaan - perusahaan yang masuk dalam indeks KOMPAS 100 rata-rata per tahun menguasai lebih dari $75 \%$ dalam volume perdagangan dan kapitalisasi pasar di
Bursa Efek Indonesia (BEI) Penelitian dilakukan terhadap Laporan Keuangan triwulan I, Laporan Keuangan tengah tahunan dan Laporan Keuangan triwulan III (nama-nama emiten yang masuk indeks KOMPAS 100 terlampir). Penelitian ini dilakukan selama 1 tahun dimulai dari bulan Februari 2018 sampai dengan Desember 2018.

Data yang digunakan dalam penelitian ini adalah data sekunder perusahaan - perusahaan yang masuk dalam perhitungan indeks KOMPAS 100 di Bursa Efek Indonesia berupa data harga saham perusahaan, volume perdagangan saham, tanggal publikasi laporan keuangan interim serta laporan keuangan interim untuk Tahun 2014, Tahun 2015 dan Tahun 2016. Periode Akuntansi yang diteliti dalam penelitian ini adalah 1 Januari 2014 sampai dengan 31 Desember 2016. Data tersebut diperoleh dari pusat data Bursa Efek Indonesia, Indonesian Capital Market Directory, situs Bursa efek Indonesia, dan situs Yahoo Finance.

Sampel penelitian dipilih dengan menggunakan metode purposive (judgment sampling method) dalam dua tahap dengan kriteria masing-masing sebagai berikut :

Tahap I Seleksi terhadap perusahaan dengan kriteria: 1) Perusahaan masuk dalam perhitungan indeks KOMPAS 100 selama 1 tahun penuh (pertengahan tahun pertama dan kedua); 2) Perusahaan bukan merupakan sektor keuangan; dan 3) Perusahaan memiliki harga pasar saham rata-rata dibawah Rp10.000,00 
Tahap II seleksi terhadap laporan keuangan interim dengan kriteria : 1) Tanggal publikasi laporan keuangan interim tidak dalam minggu yang sama dengan tanggal publikasi laporan tahunan; 2) Tanggal publikasi laporan keuangan interim tidak dalam minggu yang sama dengan tanggal publikasi deviden; dan 3) Tanggal publikasi laporan keuangan interim tidak dalam minggu yang sama dengan tanggal publikasi pemecahan saham (stock-split)

Mengikuti Landsman, Truong (2012) reaksi pasar atas publikasi laporan keuangan interim diestimasi dengan menggunakan volatilitas return abnormal/abnormal return volatility (AVAR) dan volume perdagangan abnormal labnormal Volume (AVOL) disekitar tanggal publikasi laporan keuangan interim, $\mathrm{H}-5$ sampai dengan $\mathrm{H}+5$ relatif terhadap tanggal publikasi laporan keuangan interim.

Volatilitas return abnormal/abnormal return volatility (AVAR) perusahaan i didefinisikan sebagai kuadrat dari return abnormal perusahaan i dibagi dengan varian return abnormal perusahaan i disekitar tanggal publikasi laporan keuangan interim.

\section{Hasil Dan Pembahasan}

\section{Rata-Rata Varian Return Abnormal (AVAR) dan Rata-Rata Varian Volume Abnormal (AVOL) Laporan Keuangan Interim I Diaudit}

Gambar 1 dan Gambar 2 menyajikan grafik rata-rata varian return abnormal (AVAR) dan rata-rata varian volume abnormal (AVOL) 5 hari sebelum tanggal publikasi sampai dengan 5 hari sesudah tanggal publikasi Laporan Keuangan Interim I yang diaudit.

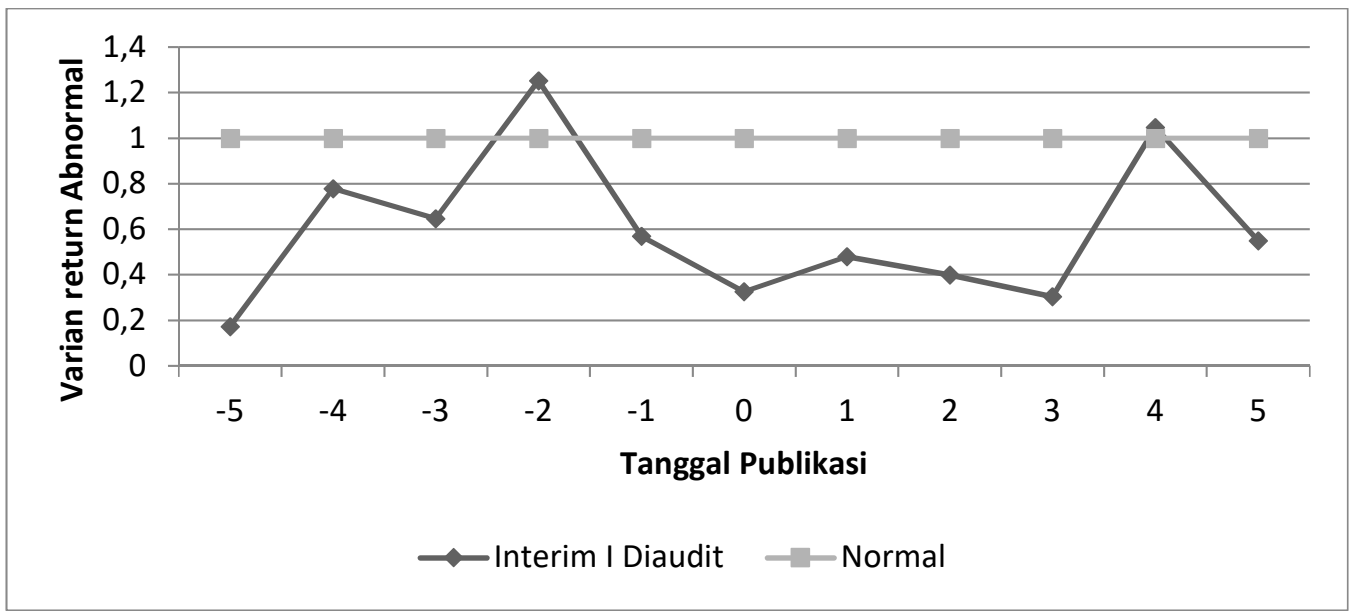

Gambar 1. Rata-Rata Varian Return Abnormal Atas Publikasi Laporan Keuangan Interim I Diaudit

Gambar 2 menunjukkan varian return abnormal (AVAR) dari H-5 sampai dengan $\mathrm{H}+5$ bernilai kurang dari satu $(<1)$ atau dibawah normal kecuali pada H-2 atau pada saat 2 hari sebelum publikasi laporan keuangan interim I audited AVAR 
mengalami peningkatan yang dramatis. Hal ini mengindikasikan bahwa informasi tentang Laporan keuangan Interim I audited telah diketahui oleh pasar sebelum pengumuman resmi laporan tersebut dirilis atau dengan kata lain Bursa efek Indonesia bukan merupakan satu-satunya sumber informasi bagi sebagian investor dalam memperoleh laporan keuangan interim I audited sehingga investor merespon laporan keuangan interim sebelum laporan tersebut dipublikasikan oleh bursa pada H-0. Varian return abnormal (AVAR) bernilai lebih dari satu $(>1)$ yang hanya terjadi pada $\mathrm{H}-2$ juga mengindikasikan bahwa pasar tidak terlalu tertarik terhadap laporan keuangan keuangan interim ini. Hal ini diperkuat dengan analisis terhadap varian volume abnormal (AVOL) laporan keuangan interim I audited yang secara keseluruhan bernilai negatif seperti tampak pada Gambar 4.

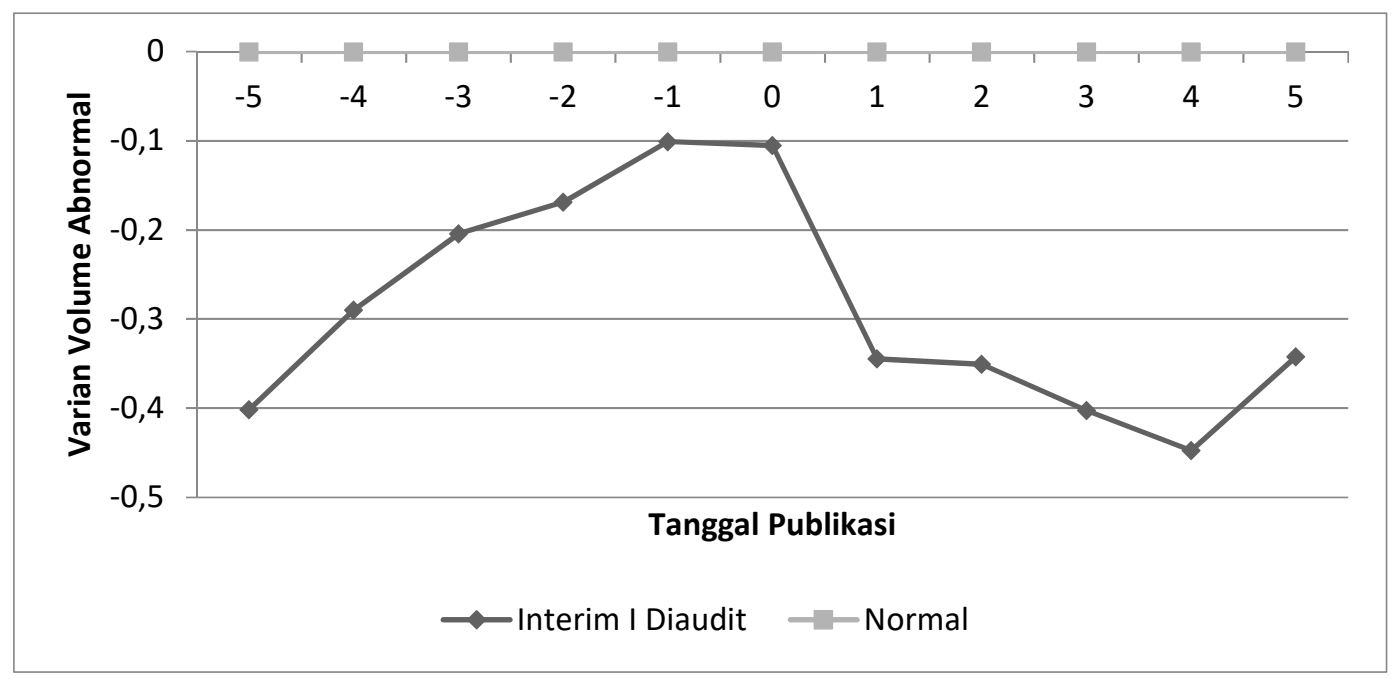

Gambar 2. Rata-Rata Varian Return Abnormal Atas Publikasi Laporan Keuangan Interim I audited

Berdasarkan gambar 2, varian volume abnormal (AVOL) dari H-5 sampai dengan $\mathrm{H}+5$ bernilai negatif (kurang dari nol $/<0)$ atau dibawah normal. Hal ini mengindikasikan bahwa berdasarkan analisis varian volume abnormal informasi tentang Laporan keuangan Interim I audited sama sekali tidak digunakan oleh investor dalam keputusan investasinya. Indikasi ini diperkuat dengan hasil pengujian hipotesis 2 berikut ini.

\section{Pengujian Hipotesis II pada Laporan Keuangan Interim I Diaudit}

Hipotesis alternatif kedua dalam penelitian ini adalah terdapat reaksi pasar atas publikasi laporan keuangan interim I yang diaudit. Hal ini dapat diketahui dengan adanya varian return abnormal $(\mathrm{AVAR})>1$ dan atau varian volume abnormal (AVOL) $>$ 0 . Pengujian statistik terhadap varian return abnormal (AVAR) atas publikasi Laporan Keuangan Interim I diaudit disajikan dalam Tabel 1 berikut ini: 
Tabel 1. Pengujian Statistik Terhadap Varian Return Abnormal (AVAR) Laporan Keuangan Interim I yang Diaudit

\begin{tabular}{cccccc}
\hline TGL & Mean & Standar Deviasi & Z Hitung & Z Tabel & Simpulan \\
\hline H-5 & 0,17278 & 0,20143 & $-2,2678$ & 1,64500 & Tidak Sig \\
H-4 & 0,77777 & 0,57901 & 0,0000 & 1,64500 & Tidak Sig \\
H-3 & 0,64582 & 0,82455 & $-0,7559$ & 1,64500 & Tidak Sig \\
H-2 & 1,25233 & 2,24736 & $-1,5119$ & 1,64500 & Tidak Sig \\
H-1 & 0,56895 & 0,73239 & $-0,7559$ & 1,64500 & Tidak Sig \\
H-0 & 0,19502 & 0,12633 & $-1,5119$ & 1,64500 & Tidak Sig \\
H+1 & 0,48017 & 0,48795 & $-0,7559$ & 1,64500 & Tidak Sig \\
H+2 & 0,39847 & 0,90704 & $-1,5119$ & 1,64500 & Tidak Sig \\
H+3 & 0,30292 & 0,44120 & $-1,5119$ & 1,64500 & Tidak Sig \\
H+4 & 1,04743 & 1,81988 & $-0,7559$ & 1,64500 & Tidak Sig \\
H+5 & 0,54876 & 0,99719 & $-1,5119$ & 1,64500 & Tidak Sig \\
\hline
\end{tabular}

Tabel 1 menyajikan pengujian statistik varian return abnormal (AVAR) Laporan Keuangan Interim I Diaudit dari perusahaan sampel. Secara keseluruhan berdasarkan hasil uji binomial satu sisi kanan menyimpulkan bahwa varian return abnormal untuk $\mathrm{H}-5$ sampai dengan $\mathrm{H}+5$ tidak berbeda dari 1 ( $\mathrm{t}$ hitung $<\mathrm{t}$ tabel). Hal yang dapat disimpulkan bahwa tidak ada alasan untuk menerima $\mathrm{Ha}$ atau dengan kata lain menerima Ho. Hal yang dapat dipetik dari pengujian ini adalah secara statistik tidak terdapat reaksi pasar atas publikasi laporan keuangan interim I Diaudit atau dengan kata lain pasar tidak merespon secara luas pengumuman laporan keuangan interim I Diaudit yang dipublikasikan oleh emiten. Kesimpulan yang sama juga dihasilkan dari pengujian terhadap varian volume abnormal (AVOL) seperti tampak pada Tabel 7 berikut ini:

Tabel 2. Pengujian Statistik Terhadap Varian Volume Abnormal (AVOL) Laporan Keuangan Interim I yang diaudit

\begin{tabular}{cccccc}
\hline TGL & Mean & Standar Deviasi & Z Hitung & Z Tabel & Simpulan \\
\hline H-5 & $-0,40171$ & 0,33445 & $-1,51186$ & 1,64500 & Tidak Sig \\
H-4 & $-0,28994$ & 0,19411 & $-1,51186$ & 1,64500 & Tidak Sig \\
H-3 & $-0,20453$ & 0,42327 & 0,00000 & 1,64500 & Tidak Sig \\
H-2 & $-0,16900$ & 0,59734 & $-1,51186$ & 1,64500 & Tidak Sig \\
H-1 & $-0,10090$ & 0,61796 & 0,00000 & 1,64500 & Tidak Sig \\
H-0 & $-0,10509$ & 0,32473 & $-0,75593$ & 1,64500 & Tidak Sig \\
H+1 & $-0,34459$ & 0,35012 & $-0,75593$ & 1,64500 & Tidak Sig \\
H+2 & $-0,35065$ & 0,40006 & $-1,51186$ & 1,64500 & Tidak Sig \\
H+3 & $-0,40265$ & 0,18162 & $-2,26779$ & 1,64500 & Tidak Sig \\
H+4 & $-0,44756$ & 0,40155 & $-1,51186$ & 1,64500 & Tidak Sig \\
H+5 & $-0,34210$ & 0,67498 & $-1,51186$ & 1,64500 & Tidak Sig \\
\hline
\end{tabular}


Tabel 2 menyajikan pengujian statistik varian volume abnormal (AVOL) Laporan Keuangan Interim I diaudit dari perusahaan sampel. Secara keseluruhan berdasarkan hasil uji binomial satu sisi kanan menyimpulkan bahwa varian return abnormal untuk $\mathrm{H}-5$ sampai dengan $\mathrm{H}+5$ tidak berbeda dari 0 ( $\mathrm{t}$ hitung $<\mathrm{t}$ tabel). Hal yang dapat disimpulkan bahwa tidak ada alasan untuk menerima $\mathrm{Ha}$ atau dengan kata lain menerima Ho. Hal yang dapat dipetik dari pengujian ini adalah secara statistik tidak terdapat reaksi pasar atas publikasi laporan keuangan interim I Diaudit atau dengan kata lain pasar tidak merespon secara luas pengumuman laporan keuangan interim I Diaudit yang dipublikasikan oleh emiten.

Berdasarkan diskriptif dan pengujian statistik terhadap AVAR dan AVOL tampak bahwa secara diskriptif ukuran sentral dan juga pengujian statistik memberikan indikasi bahwa pasar tidak merespon publikasi Laporan Keuangan Interim I yang diaudit. Hal yang dapat dipetik dari hasil ini adalah bahwa kesimpulan hasil pengujian statistik Iterhadap AVAR dan AVOL Laporan Keuangan Interim I yang diaudit tidak konsisten dengan pengujian statistik terhadap Laporan Keuangan Interim I sebelumnya. Hal lain yang dapat dipetik dari temuan ini adalah bahwa investor tidak tertarik terhadap laporan keuangan interim I yang diaudit sehingga pasar tidak merespon terhadap publikasi laporan keuangan interim I yang diaudit.

Reaksi Pasar atas Publikasi Laporan Keuangan Interim II Diaudit, Rata-Rata Varian Return Abnormal (AVAR) dan Rata-Rata Varian, Volume Abnormal (AVOL) Laporan Keuangan Interim II Diaudit

Gambar 3 dan Gambar 4 menyajikan grafik rata-rata varian return abnormal (AVAR) dan rata-rata varian volume abnormal (AVOL) 5 hari sebelum tanggal publikasi sampai dengan 5 hari sesudah tanggal publikasi Laporan Keuangan Interim II yang diaudit.

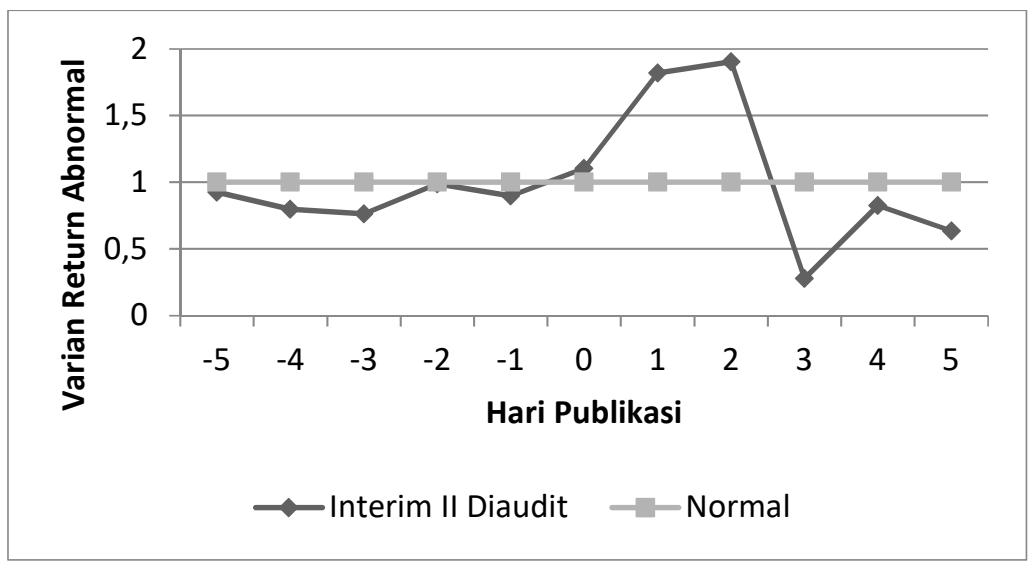

Gambar 3. Rata-Rata Varian Return Abnormal Atas Publikasi Laporan Keuangan Interim II Diaudit 
Berdasarkan Gambar 3 dapat dilihat bahwa varian return abnormal (AVAR) dari $\mathrm{H}-5$ sampai dengan $\mathrm{H}-1$ bernilai kurang dari satu $(<1)$ atau dibawah normal kemudian varian return abnormal (AVAR) mulai bernilai diatas normal pada saat hari publikasi laporan keuangan interim II diaudit dan mengalami kenaikan yang dramatis pada $\mathrm{H}+1$ dan $\mathrm{H}+2$ sebelum kembali di bawah normal pada $\mathrm{H}+3$ sampai dengan $\mathrm{H}+5$.

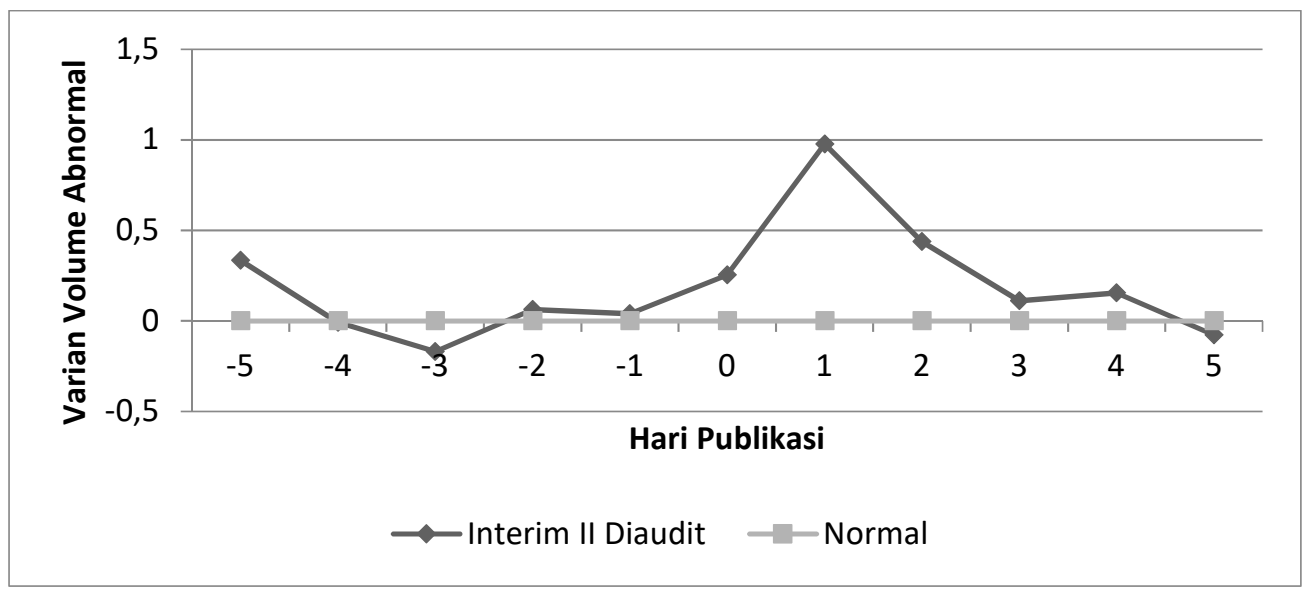

Gambar 4. Rata-Rata Varian Volume Abnormal Atas Publikasi Laporan Keuangan Interim II audited

Gambar 4 menyajikan grafik rata-rata varian volume abnormal (AVOL) 5 hari sebelum tanggal publikasi sampai dengan 5 hari sesudah tanggal publikasi Laporan Keuangan Interim II diaudit. Dari Gambar 4 tampak bahwa varian volume abnormal (AVOL) pada $\mathrm{H}-2$ sampai dengan $\mathrm{H}+4$ berada di atas normal dan mengalami peningkatan secara dramatis pada $\mathrm{H}+1$ sebelum bergerak turun setelahnya tetapi tetap diatas normal sampai $\mathrm{H}+4$. Peningkatan yang dramatis $\mathrm{H}+1$ dan tetap diatas normal sampai dengan $\mathrm{H}+4$ mengindikasikan bahwa selain investor berhati-hati dalam mengevaluasi Laporan Keuangan Interim II tampak bahwa pasar cenderung lambat dan tidak merata dalam merespon informasi laporan keuangan interim II diaudit secara keseluruhan Gambar 4 mengindikasikan laporan keuangan interim II digunakan oleh investor sebagai salah satu sumber informasi dalam keputusan portofolionya.

\section{Pengujian Hipotesis II pada Laporan Keuangan Interim II Diaudit}

Hipotesis alternatif kedua dalam penelitian ini adalah terdapat reaksi pasar atas publikasi laporan keuangan interim II yang diaudit. Hal ini dapat diketahui dengan adanya varian return abnormal (AVAR) $>1$ dan atau varian volume abnormal (AVOL) $>$ 0 Pengujian statistik terhadap varian return abnormal (AVAR) atas publikasi Laporan Keuangan Interim II diaudit disajikan dalam Tabel 3 berikut ini: 
Tabel 3. Pengujian Statistik Terhadap Varian Return Abnormal (AVAR) Laporan Keuangan Interim II yang Diaudit

\begin{tabular}{cccccl}
\hline TGL & Mean & Standar Deviasi & Z Hitung & Z Tabel & Simpulan \\
\hline H-5 & 0,92427 & 2,15737 & $-0,97014$ & 1,64500 & Tidak Sig \\
H-4 & 0,79605 & 0,96263 & $-0,48507$ & 1,64500 & Tidak Sig \\
H-3 & 0,76259 & 0,77079 & $-0,48507$ & 1,64500 & Tidak Sig \\
H-2 & 0,98657 & 1,22323 & $-0,48507$ & 1,64500 & Tidak Sig \\
H-1 & 0,89807 & 0,95429 & $-0,48507$ & 1,64500 & Tidak Sig \\
H-0 & 1,10482 & 1,67029 & $-0,97014$ & 1,64500 & Tidak Sig \\
H+1 & 1,82053 & 2,31719 & 0,00000 & 1,64500 & Tidak Sig \\
H+2 & 1,90365 & 1,64353 & 0,97014 & 1,64500 & Tidak Sig \\
H+3 & 0,27733 & 0,40985 & $-2,42536$ & 1,64500 & Tidak Sig \\
H+4 & 0,82510 & 1,01292 & $-1,45521$ & 1,64500 & Tidak Sig \\
H+5 & 0,63447 & 0,76955 & $-1,45521$ & 1,64500 & Tidak Sig \\
\hline
\end{tabular}

Tabel 3 menyajikan pengujian

menerima $\mathrm{Ha}$ atau dengan kata lain statistik varian return abnormal (AVAR) menerima Ho. Secara statistik tidak terdapat Laporan Keuangan Interim II Diaudit dari reaksi pasar atas publikasi laporan keuangan perusahaan sampel. Secara keseluruhan interim II Diaudit atau dengan kata lain pasar berdasarkan hasil uji binomial satu sisi kanan menyimpulkan bahwa varian return abnormal untuk $\mathrm{H}-5$ sampai dengan $\mathrm{H}+5$ tidak berbeda dari 1 ( $\mathrm{t}$ hitung $<\mathrm{t}$ tabel). Hal yang dapat disimpulkan bahwa tidak ada alasan untuk tidak merespon secara luas pengumuman laporan keuangan interim II Diaudit yang dipublikasikan oleh emiten berdasarkan pengujian atas varian return abnormal (AVAR).

Tabel 4. Pengujian Statistik Terhadap Varian Volume Abnormal (AVOL) Laporan Keuangan Interim II yang diaudit

\begin{tabular}{cccccc}
\hline TGL & Mean & Standar Deviasi & Z Hitung & Z Tabel & Simpulan \\
\hline H-5 & 0,33323 & 1,29451 & $-0,48507$ & 1,64500 & Tidak Sig \\
H-4 & $-0,00935$ & 0,66637 & $-0,48507$ & 1,64500 & Tidak Sig \\
H-3 & $-0,16912$ & 0,74025 & $-1,45521$ & 1,64500 & Tidak Sig \\
H-2 & 0,06262 & 1,06762 & $-0,97014$ & 1,64500 & Tidak Sig \\
H-1 & 0,03898 & 0,66635 & $-0,48507$ & 1,64500 & Tidak Sig \\
H-0 & 0,25292 & 2,01168 & $-1,45521$ & 1,64500 & Tidak Sig \\
H+1 & 0,97561 & 1,64481 & 1,94029 & 1,64500 & Sig \\
H+2 & 0,43818 & 1,27924 & 0,48507 & 1,64500 & Tidak Sig \\
H+3 & 0,11115 & 1,00471 & $-0,48507$ & 1,64500 & Tidak Sig \\
H+4 & 0,15499 & 1,21096 & $-0,97014$ & 1,64500 & Tidak Sig \\
H+5 & $-0,07844$ & 0,78529 & $-0,97014$ & 1,64500 & Tidak Sig \\
\hline
\end{tabular}


Tabel 4 menyajikan pengujian statistik varian volume abnormal (AVOL) Laporan Keuangan Interim II Diaudit dari perusahaan sampel. Secara keseluruhan berdasarkan hasil uji binomial satu sisi kanan menyimpulkan bahwa varian volume abnormal (AVOL) untuk untuk H-5 sampai dengan $\mathrm{H}+5$ tidak berbeda dari 1 ( $\mathrm{t}$ hitung $<\mathrm{t}$ tabel) kecuali pada $\mathrm{H}+1$. $\mathrm{z}$ hitung pada $\mathrm{H}+1$ sebesar 1,94029 sedangkan $\mathrm{z}$ tabel untuk tingkat signifikasi $5 \%$ pengujian satu arah bernilai 1,64500. Karena z hitung lebih besar dari $\mathrm{z}$ tabel $(1,94029>1,64500)$ maka tidak ada alasan untuk menerima Ho atau dengan kata lain Ha diterima. Hal yang dapat disimpulkan bahwa secara statistik berdasarkan varian volume abnormal (AVOL) terdapat reaksi pasar atas publikasi laporan keuangan interim II diaudit atau dengan kata lain pasar merespon secara luas pengumuman laporan keuangan interim II diaudit yang dipublikasikan oleh emiten.

Berdasarkan diskriptif dan pengujian statistik terhadap AVAR dan AVOL tampak bahwa secara diskriptif ukuran sentral dan juga pengujian statistik memberikan indikasi bahwa pasar merespon publikasi Laporan Keuangan Interim II yang diaudit. Hal yang dapat dipetik dari hasil ini adalah bahwa kesimpulan hasil pengujian statistik terhadap AVAR dan AVOL Laporan Keuangan Interim II yang diaudit konsisten dengan pengujian statistik terhadap Laporan Keuangan Interim II sebelumnya. Hal lain yang dapat dipetik dari temuan ini adalah untuk laporan keuangan interim II diaudit investor tetap tertarik menggunakannya sebagai salah satu sumber informasi dalam keputusan investasinya walaupun laporan ini dipublikasikan tiga bulan setelah periode laporan keuangan interim II berakhir dan laporan keuangan interim III tidak diaudit akan dipublikasikan.

\section{Reaksi Pasar atas Publikasi Laporan Keuangan Interim III Diaudit}

\section{Rata-Rata Varian Return Abnormal (AVAR) dan Rata-Rata Varian Volume Abnormal (AVOL) Laporan Keuangan Interim III Diaudit}

Gambar 5 dan Gambar 6 menyajikan grafik rata-rata varian return abnormal (AVAR) dan rata-rata varian volume abnormal (AVOL) 5 hari sebelum tanggal publikasi sampai dengan 5 hari sesudah tanggal publikasi Laporan Keuangan Interim III yang diaudit. 


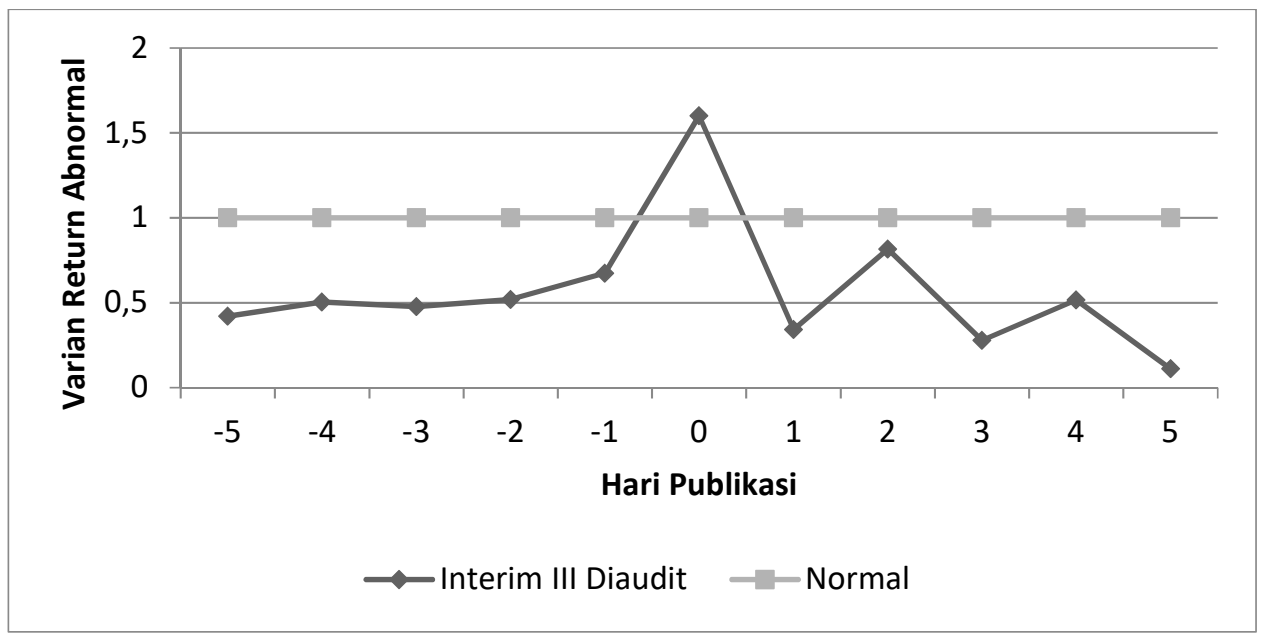

Gambar 5. Rata-Rata Varian Return Abnormal Atas Publikasi Laporan Keuangan Interim III Diaudit

Gambar 5 menunjukkan varian return abnormal (AVAR) dari H-5 sampai dengan $\mathrm{H}+5$ bernilai kurang dari satu $(<1)$ atau dibawah normal kecuali untuk H-0 atau pada saat publikasi laporan keuangan interim III diaudit varian return abnormal (AVAR) berada di atas normal. Hal ini mengindikasikan bahwa investor tidak terlalu tertarik terhadap informasi ini sehingga investor hanya menggunakan informasi ini pada saat tanggal publikasi dan tidak untuk hari-hari selanjutnya. Walaupun demikian, adanya varian return abnormal (AVAR) diatas normal pada $\mathrm{H}-0$ hal ini mengindikasikan pasar masih merespon atas publikasi laporan keuangan interim III yang diaudit. Hal ini diperkuat dengan analisis diskriptif terhadap varian volume abnormal seperti tampak pada gambar 6 berikut ini.

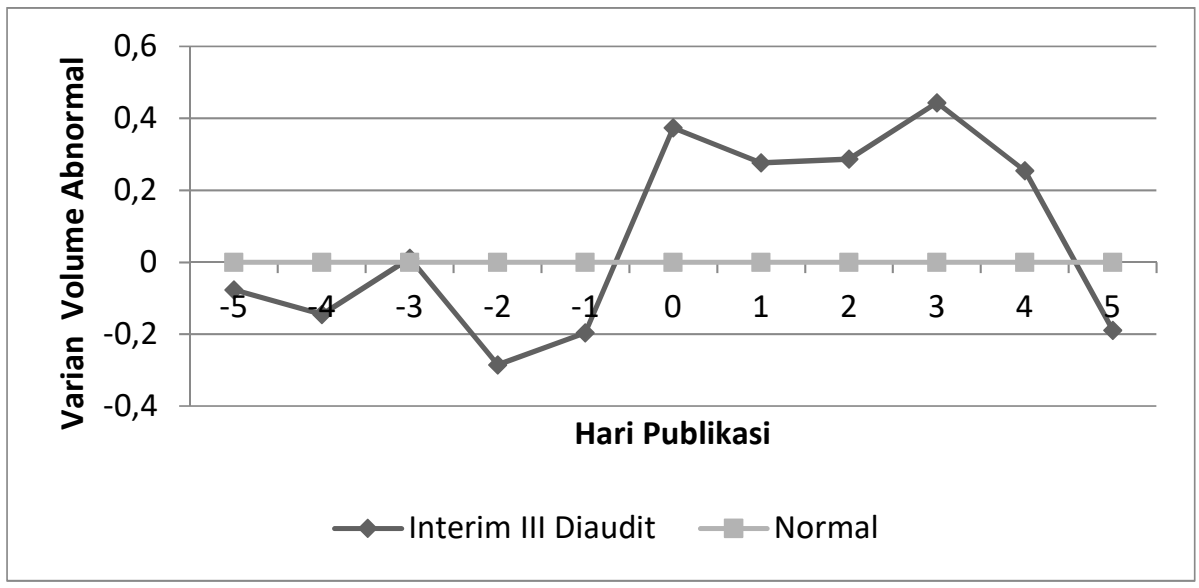

Gambar 6. Rata-Rata Varian Volume Abnormal Atas Publikasi Laporan Keuangan Interim III audited 
Gambar 6 menunjukkan bahwa varian volume abnormal (AVOL) dari $\mathrm{H}-5$ sampai dengan $\mathrm{H}-1$ bernilai kurang dari satu $(<1)$ atau dibawah normal kemudian varian volume abnormal (AVOL) mulai bernilai diatas normal pada saat hari publikasi laporan keuangan interim III diaudit dan mengalami kenaikan yang dramatis pada $\mathrm{H}+0$ dan $\mathrm{H}+3$ sebelum kembali di bawah normal pada $\mathrm{H}+5$. varian volume abnormal (AVOL) mulai mengalami kenaikan yang dramatis pada $\mathrm{H}+1$ dan $\mathrm{H}+3$ selain mengindikasikan lambatnya pasar dalam menyerap informasi juga mengindikasikan sikap kehati-hatian investor dalam mengevaluasi informasi yang ada dalam laporan keuangan interim III diaudit. Secara keseluruhan rata-rata varian volume abnormal (AVOL) laporan keuangan interim III diaudit pada Gambar 6 mengindikasikan reaksi pasar atas publikasi laporan keuangan interim III diaudit atau dengan kata lain investor menggunakan informasi yang ada dalam laporan keuangan interim III diaudit dalam keputusan investasinya.

\section{Pengujian Hipotesis II pada Laporan Keuangan Interim III Diaudit}

Hipotesis alternatif kedua dalam penelitian ini adalah terdapat reaksi pasar atas publikasi laporan keuangan interim III yang diaudit. Hal ini dapat diketahui dengan adanya varian return abnormal (AVAR) $>1$ dan atau varian volume abnormal (AVOL) $>$ 0 . Pengujian statistik terhadap varian return abnormal (AVAR) atas publikasi Laporan Keuangan Interim III diaudit disajikan dalam Tabel 6 berikut ini:

Tabel 6. Pengujian Statistik Terhadap Varian Return Abnormal (AVAR) Laporan Keuangan Interim III yang Diaudit

\begin{tabular}{llllll}
\hline TGL & Mean & Standar Deviasi & Z Hitung & Z Tabel & Simpulan \\
\hline H-5 & 0,42167 & 0,69584 & $-1,51186$ & 1,64500 & Tidak Sig \\
H-4 & 0,50309 & 0,32314 & $-0,75593$ & 1,64500 & Tidak Sig \\
H-3 & 0,47804 & 0,57302 & $-0,75593$ & 1,64500 & Tidak Sig \\
H-2 & 0,51756 & 0,55029 & $-1,51186$ & 1,64500 & Tidak Sig \\
H-1 & 0,67384 & 0,50860 & 0,00000 & 1,64500 & Tidak Sig \\
H-0 & 1,60130 & 1,20463 & 0,75593 & 1,64500 & Tidak Sig \\
H+1 & 0,34168 & 0,27186 & $-1,51186$ & 1,64500 & Tidak Sig \\
H+2 & 0,81571 & 1,36847 & $-1,51186$ & 1,64500 & Tidak Sig \\
H+3 & 0,27778 & 0,24816 & $-0,75593$ & 1,64500 & Tidak Sig \\
H+4 & 0,51522 & 0,36411 & $-0,75593$ & 1,64500 & Tidak Sig \\
H+5 & 0,11112 & 0,16304 & $-1,51186$ & 1,64500 & Tidak Sig \\
\hline
\end{tabular}

Tabel 6 menyajikan statistik varian return abnormal (AVAR) Laporan Keuangan Interim III diaudit dari perusahaan sampel. Secara keseluruhan berdasarkan hasil uji binomial satu sisi kanan menyimpulkan bahwa varian return abnormal untuk $\mathrm{H}-5$ sampai dengan $\mathrm{H}+5$ tidak berbeda dari $1(\mathrm{t}$ hitung $<\mathrm{t}$ tabel). Maka tidak ada alasan untuk menerima $\mathrm{Ha}$ atau dengan kata lain hasil pengujian hipotesis menerima Ho. Hal 
yang dapat disimpulkan bahwa secara statistik berdasarkan varian return abnormal (AVAR) tidak terdapat reaksi pasar atas publikasi laporan keuangan interim III diaudit atau dengan kata lain pasar tidak merespon secara luas pengumuman laporan keuangan interim III diaudit yang dipublikasikan oleh emiten. Kesimpulan yang sama juga dihasilkan dari pengujian terhadap varian volume abnormal (AVOL) seperti tampak pada Tabel 7 berikut ini.

Tabel 7. Pengujian Statistik Terhadap Varian Volume Abnormal (AVOL) Laporan Keuangan Interim III yang diaudit

\begin{tabular}{cccccc}
\hline TGL & Mean & Standar Deviasi & Z Hitung & Z Tabel & Simpulan \\
\hline H-5 & $-0,07745$ & 0,98843 & $-0,31623$ & 1,64500 & Tidak Sig \\
H-4 & $-0,14564$ & 0,63374 & $-0,94868$ & 1,64500 & Tidak Sig \\
H-3 & 0,01098 & 1,19137 & $-0,31623$ & 1,64500 & Tidak Sig \\
H-2 & $-0,28524$ & 0,48163 & $-0,31623$ & 1,64500 & Tidak Sig \\
H-1 & $-0,19633$ & 0,70471 & 0,31623 & 1,64500 & Tidak Sig \\
H-0 & 0,37401 & 1,21642 & 0,31623 & 1,64500 & Tidak Sig \\
H+1 & 0,27661 & 0,77096 & 0,31623 & 1,64500 & Tidak Sig \\
H+2 & 0,28701 & 0,60947 & 0,31623 & 1,64500 & Tidak Sig \\
H+3 & 0,44338 & 1,23225 & $-0,31623$ & 1,64500 & Tidak Sig \\
H+4 & 0,25415 & 0,96285 & 0,31623 & 1,64500 & Tidak Sig \\
H+5 & $-0,18887$ & 0,38013 & $-0,31623$ & 1,64500 & Tidak Sig \\
\hline
\end{tabular}

Tabel 7 menyajikan statistik varian volume abnormal (AVOL) Laporan Keuangan Interim III diaudit dari perusahaan sampel. Secara keseluruhan berdasarkan hasil uji binomial satu sisi kanan menyimpulkan bahwa varian volume abnormal (AVOL) untuk H-5 sampai dengan $\mathrm{H}+5$ tidak berbeda dari 0 ( $\mathrm{t}$ hitung $<\mathrm{t}$ tabel) . Maka tidak ada alasan untuk menerima $\mathrm{Ha}$ atau dengan kata lain hasil pengujian hipotesis menerima Ho. Hal yang dapat disimpulkan bahwa secara statistik berdasarkan varian volume abnormal (AVOL) tidak terdapat reaksi pasar atas publikasi laporan keuangan interim III diaudit atau dengan kata lain pasar tidak merespon secara luas pengumuman laporan keuangan interim III diaudit yang dipublikasikan oleh emiten.

Berdasarkan diskriptif dan pengujian statistik terhadap AVAR dan AVOL tampak bahwa walaupun secara diskriptif ukuran sentral memberikan indikasi bahwa pasar merespon publikasi Laporan Keuangan Interim III yang diaudit namun pengujian statistik gagal untuk membuktikan indikasi tersebut. Hal yang dapat dipetik dari hasil ini adalah untuk laporan keuangan interim III diaudit investor tidak begitu tertarik menggunakannya sebagai salah satu sumber informasi dalam keputusan investasinya. 


\section{Kesimpulan}

Sejalan dengan signaling theory, terdapat reaksi pasar atas publikasi Laporan Keuangan Interim I dan Laporan Keuangan Interim II. Dengan kata lain, pasar merespon secara luas pengumuman Laporan Keuangan Interim I dan Laporan Keuangan Interim II yang dipublikasikan oleh emiten. Hal ini menunjukkan bahwa publikasi laporan keuangan interim I dan II memberikan sinyal tentang kondisi dan kinerja perusahaan sehingga investor tertarik untuk melakukan perdagangan saham. Di sisi lain pasar tidak merespon secara luas pengumuman Laporan Keuangan Interim III yang dipublikasikan oleh emiten. Hal ini dilatar belakangi oleh jumlah frekuensi pelaporan yang lebih sering menyebabkan tingkat asimetri informasi yang lebih rendah antara prinsipal dan agen sehingga laporan keuangan interim I dan laporan keuangan interim II cukup andal untuk memprediksi laba atau informasi yang terkandung pada laporan keuangan interim III. Pada akhirnya, implikasi dari temuan ini adalah akan lebih baik jika emiten mempertimbangkan untuk tidak melibatkan auditor dalam laporan keuangan interim dan langsung mempublikasikan laporan keuangan tersebut sesaat setelah periode interim berakhir.

\section{Daftar Pustaka}

Jurnal:

Bedard, J., Chtourou, S. M., Courteau, L. (2004). The Effect of Audit Committee Expertise, Independence, and Activity on Aggressive Earnings Management. Auditing: A Journal of Practice \& Theory 23
Bursa Efek Indonesia. 2004. Peraturan Nomor I-E tentang Kewajiban Penyampaian Informasi. KepDir PT BEI Nomor : Kep-306/BEJ/07-2004 (www.bei.co.id, diakses 2 Februari 2013)

Ikatan Akuntan Indonesia. 2018. Standar Akuntansi Keuangan per 1 Juni 2018. Ikatan Akuntan Indonesia (IAI), Jakarta, Indonesia

Indrastanti, Sri Retno, 1998 Pengaruh Pengumuman Laporan Keuangan Interim di Pasar Modal. Jurnal Emperika, No.22

Jatiningrum, Citrawati, 2009, Analisis Pengaruh Publikasi Laporan Keuangan Interim Terhadap Abnormal Return Saham Di Bursa Efek Indonesia (BEI), JMK Vol. 7 No. 3. Darmajaya. Lampung

Landsman, W. R., E. L. Maydew, and J. R. Thornock. 2012. The Information Content of Annual Earnings Announcements and Mandatory Adoption of IFRS. Journal of Accounting and Economics, 53 (2)

Mangena, Musa, Venancio Tauringana dan Eddie Chamisa. 2012. "Corporate Boards, Ownership Structure and Firm Performance in an Environment of Severe Political and Economic Crisis". British Journal of Management 23.

Suyatno. 2003. Pengaruh Informasi Laporan Keuangan Interim Sebelum dan Sesudah Pengumuman Terhadap harga Saham di BEJ. Tesis Program Magister Akuntansi Program Pascasarjana Universitas Diponegoro (Tidak dipublikasikan). (http://eprints.undip.ac.id/10661/1/200 3MAK2216.pdf, diakses 23 Januari 2013).

Truong, C. 2012. Information content of earnings announcements in the New Zealand equity market, a longitudinal analysis. Accounting and Finance (52) (2012 Suppl. 